\title{
A Systematic Literature Review of the Childbearing Cycle as Experienced by Survivors of Sexual Abuse
}

Jenna A. LoGiudice

Fairfield University, jlogiudice@fairfield.edu

Follow this and additional works at: https://digitalcommons.fairfield.edu/nursing-facultypubs

Copyright 2017 Elsevier

Post-print archived here with permission from the copyright holder.

Creative Commons Attribution Non-Commercial No Derivatives License

\section{Peer Reviewed}

\section{Repository Citation}

LoGiudice, Jenna A., "A Systematic Literature Review of the Childbearing Cycle as Experienced by Survivors of Sexual Abuse" (2017). Nursing and Health Studies Faculty Publications. 92.

https://digitalcommons.fairfield.edu/nursing-facultypubs/92

\section{Published Citation}

LoGiudice, Jenna Alana. "A Systematic Literature Review of the Childbearing Cycle as Experienced by Survivors of Sexual Abuse." Nursing for women's health 20, no. 6 (2017): 582-594.

This item has been accepted for inclusion in DigitalCommons@Fairfield by an authorized administrator of DigitalCommons@Fairfield. It is brought to you by DigitalCommons@Fairfield with permission from the rightsholder(s) and is protected by copyright and/or related rights. You are free to use this item in any way that is permitted by the copyright and related rights legislation that applies to your use. For other uses, you need to obtain permission from the rights-holder(s) directly, unless additional rights are indicated by a Creative Commons license in the record and/or on the work itself. For more information, please contact digitalcommons@fairfield.edu. 


\section{CNE}

\section{A Systematic Literature Review of the Childbearing Cycle as Experienced by Survivors of Sexual Abuse}

Jenna Alana LoGiudice

\section{Objectives}

Upon completion of this activity, the learner will be able to:

1. List current statistics on women's risk of sexual abuse.

2. Summarize the methods and results of the studies including in this systematic review.

3. Describe actions that nurses and other health care providers can take to help women who have experienced sexual abuse have a more positive experience of pregnancy, labor, and childbirth.

\section{Continuing Nursing Education (CNE) Credit}

A total of 1.2 contact hours may be earned as CNE credit for reading "A Systematic Literature Review of the Childbearing Cycle as Experienced by Survivors of Sexual Abuse" and for completing an online posttest and participant feedback form.

To take the test and complete the participant feedback form, please visit http://www.awhonn.org/?OnlineLearningCenter. Certificates of completion will be issued on receipt of the completed participant feedback form and any processing fees.

Association of Women's Health, Obstetric and Neonatal Nurses is accredited as a provider of continuing nursing education by the American Nurses Credentialing Center's Commission on Accreditation.

Accredited status does not imply endorsement by AWHONN or ANCC of any commercial products displayed or discussed in conjunction with an educational activity.

AWHONN is approved by the California Board of Registered Nursing, provider \#CEP580.

Jenna Alana LoGiudice, PhD, CNM, RN, is an assistant professor in the Egan School of Nursing and Health Studies at Fairfield University in Fairfield, CT and a practicing midwife. The author and planners of this activity report no conflicts of interest or relevant financial relationships. No commercial support was received for this learning activity. Address correspondence to: jlogiudice@fairfield.edu. 


\begin{abstract}
For women who have experienced sexual abuse, the physical changes associated with pregnancy and the lack of control during birth can be catalysts for trauma from past abuse to resurface. This systematic review offers women's health care providers a thorough evaluation of the state of the science on survivors' childbearing experiences. The literature reveals that lack of control, dissociation, and flashbacks are common themes. Re-experiencing of the trauma occurred during various stages of childbirth and was traumatizing to women. Nurses and other clinicians providing care to childbearing women can provide control to survivors during health care encounters and can form therapeutic relationships to help them have more positive childbirth experiences.
\end{abstract}

Keywords childbearing, labor and birth, pregnancy, sexual abuse, systematic review 
"My doctor, and even my therapist, vigorously assured me that these issues would not come up during labor, as I would be too busy just having a baby. From my perspective now I can assert that there is no time more likely than a birthing for this type of issue to come to the surface! After all, the memories of sexual abuse are surely locked in those muscles that are so powerfully stretched during the birth process, especially if the abuse was very traumatic to the child." (Rose, 1992, p. 215)

\section{Introduction}

The Centers for Disease Control and Prevention (CDC) defines sexual abuse as "a sexual act committed or attempted by another person without freely given consent of the victim or against someone who is unable to consent or refuse" (Basile, Smith, Breiding, Black, \& Mahendra, 2014, p.11). The prevalence and consequences of such abuse is staggering. A meta-analysis of the worldwide prevalence of sexual abuse revealed that in the United States, 201 per 1,000 girls under the age of 18 experience childhood sexual abuse (Stoltenborgh, van Ijzendoorn, Euser, \& Bakermans-Kranenburg, 2011). The global prevalence of childhood sexual abuse is $11.8 \%$, making the U.S. prevalence nearly double this rate (Stoltenborgh et al., 2011). Cantor et al. (2015) report that $23 \%$ of women are sexually assaulted on college campuses. Overall, U.S. women face approximately a one in five (19.3\%) chance of being sexually abused in their lifetime (Breiding et al., 2014). The long-term impact of trauma such as sexual abuse demands careful attention to the health care needs of survivors. A focus on the childbearing experience is critical, given that connections to past trauma have been reported to resurface and adversely influence survivors' childbearing experiences.

A woman's childbearing experience can be negatively affected by a fear-mediated response caused by past trauma (Heimstad, Dahloe, Laache, Skogvoll, \& Schei, 2006; Schwerdtfeger \& Wampler, 2009). Research in this area has demonstrated that women who have experienced sexual abuse have higher stress levels and are at greater risk for preterm birth and more difficult pregnancies and childbirth experiences than their counterparts (Benedict, Paine, 
Paine, Brandt, \& Stallings, 1999; Jacobs, 1992; Leeners, Rath, Block, Görres, \& Tschudin, 2014). Compared to women without a history of sexual abuse, "survivors reported longer labors, longer pregnancies, higher birth weights, more pregnancy terminations, earlier age at first pregnancy, more medical problems, greater stresses, and more use of ultrasound during first pregnancies" (Jacobs, 1992, p. 103). Women with a history of rape experience a longer second stage of labor, more pregnancy terminations, and more miscarriages, and are more likely to be single mothers, to be unemployed, to smoke cigarettes, and to have a higher body mass index (BMI) than those without this history (Nerum et al., 2010). Additionally, they are more likely to have a cesarean birth or operative-assisted birth (Nerum et al., 2010).

Childbearing has been identified as one of women's strongest learning experiences (Belenky, Clinchy, Goldberger, \& Tarule, 1997). For survivors of sexual abuse, the physical changes associated with pregnancy and a feeling of lack of control during labor and birth may be catalysts for trauma from past abuse(s) to permeate the childbearing experience.

\section{Review Objectives}

Given the prevalence and consequences of sexual abuse, it is imperative that nurses and other women's health care providers understand the distinct needs of these women during the childbearing period. A critical look at the literature published over the past 25 years helps provide such insight, and is presented in this systematic literature review. The first article published on this topic was a personal story (Rose, 1992). Rose's seminal story was the first to articulate sexual abuse survivor's hopes and the fears of giving birth. Reference to this narrative is crucial to understand that it was not until this woman spoke out about her experience of childhood sexual abuse and its connection to childbirth that research began in this area. After Rose's story, eight more personal accounts were published by survivors after they had given 
birth, or by midwives who attended the births of survivors (Hanan, 2006; Lewars, 2006; Rouf, 1999; Skinner, 2010; Smith, 1998a, 1998b; Tilley, 2000; Waymire, 1997). With this systematic review I hope to offer women's health care providers a thorough evaluation of the state of the science on the childbearing experience of survivors of sexual abuse.

\section{Review Method}

With the assistance of a research librarian, I conducted an exhaustive search of the literature using the following databases: Cumulative Index to Nursing and Allied Health Literature (CINAHL), PubMed, PsychINFO, and Scopus. These searches included articles published from 1990 to 2016 and used the following keywords: sexual abuse, sexual assault, sexual abuse survivor*, or sexual assault survivor* AND childbirth, childbearing, postpartum or pregnan*. Also, within PubMed and CINAHL, the specific keyword combinations of sexual abuse AND pregnan*; sexual abuse AND childbirth; sexual abuse AND postpartum; and primary care AND sexual abuse survivor* were used. A hand search was conducted using the reference lists of identified articles to locate any primary sources that did not come up during the original search, and published abstracts written in English were reviewed to determine if they met the inclusion criterion, namely that the study examined the pregnancy and/or childbirth experience of survivors of sexual abuse. Unpublished work and personal stories were excluded from this review.

\section{Review Results}

Quantitative publications $(\mathrm{N}=6)$ were reviewed and excluded because they did not meet the inclusion criteria of examining the childbearing experience. Theoretical publications $(\mathrm{N}=2)$, unpublished dissertations $(\mathrm{N}=6)$, an unpublished master's thesis $(\mathrm{N}=1)$, studies on traumatic birth $(\mathrm{N}=2)$, personal stories $(\mathrm{N}=9)$ on the childbearing experience of survivors were reviewed and 
excluded. Personal stories offer robust insight into a survivor's individual experience; however, they reveal no generalizable findings.

The search revealed 10 qualitative research studies and one meta-synthesis on the childbearing experiences of survivors of sexual abuse published between 1994 and 2016, which met inclusion criteria. The 10 qualitative studies come from a variety of disciplines and were conducted in several countries. Seven are from the discipline of nursing, one from both nursing and medicine, and one each from medicine and human development/family science. Six were conducted in the United States, two in Australia, one in Norway, and one in the United Kingdom. Grounded theory, descriptive design, and phenomenology were the most common qualitative research designs utilized. More information regarding specific characteristics of these studies can be found in Table 1.

Half of the studies $(\mathrm{n}=5)$ focused specifically on survivors of childhood sexual abuse (Coles \& Jones, 2009; Montgomery, Pope, \& Rogers, 2015a, 2015b; Parratt, 1994; Rhodes \& Hutchinson, 1994; Roller, 2011). Four studies focused on survivors of sexual trauma (Burian, 1995; Halvorsen, Nerum, Oian, \& Sørlie, 2013; LoGiudice \& Beck, 2016; Schwerdtfeger \& Wampler, 2009). Only one study focused on women with both a history of childhood sexual abuse and with abuse-related posttraumatic stress (Seng, Sparbel, Low, \& Killion, 2002). Two of the studies also included health care providers or professionals, including nurse-midwives, nurses, labor and birth/obstetric nurses, and childbirth educators, some of whom were survivors themselves (Burian, 1995; Rhodes \& Hutchinson, 1994). Five studies focused on both the pregnancy and childbirth (labor and birth) experience of survivors (Coles \& Jones, 2009; LoGiudice \& Beck, 2016; Montgomery, et al., 2015b; 2015b; Roller, 2001; Seng et al., 2002). Four studies focused exclusively on the childbirth (labor and birth) experience of survivors 
(Burian, 1995; Halvorsen et al., 2013; Parratt, 1994; Rhodes \& Hutchinson, 1994). Only one study focused solely on the pregnancy experience of survivors (Schwerdtfeger \& Wampler, 2009). One study included interviews conducted with survivors while they were pregnant, and the remaining studies were conducted retrospectively (Schwerdtfeger \& Wampler, 2009). The range of time between survivors having given birth to participating in the study ranged from one week to 28 years (Montgomery et al., 2015a, 2015b; Parratt, 1994; Seng et al., 2002).

In addition to qualitative studies, a meta-synthesis that included both published literature and unpublished dissertations on the maternity care needs of women who were sexually abused in childhood was found (Montgomery, 2013). The following section will provide a chronological review of each of the eleven research studies identified in this systematic review. Following the review, a synthesis of existing knowledge is provided.

\section{Systematic Literature Review}

Parratt (1994), a midwife, conducted a phenomenological study to examine the childbirth experiences of survivors of incest in Australia. Analysis of the six participants' semi-structured interviews found that memories, or flashbacks, of the past abuse were triggered by the childbearing experience. Parratt (1994) noted that responses to these flashbacks were individualized for each survivor. Privacy, touch, and control were identified as important issues for abuse survivors during childbirth. Survivors largely lacked control during childbirth. Being touched, especially in areas of the body related to incest, caused some women to recall the past abuse. During the immediate postpartum period, touching their babies (i.e., wanting or not wanting to touch them) was an important issue. Parratt (1994) concluded that women must have individualized care during childbirth.

Also in 1994, but in the United States, Rhodes and Hutchinson used the ethnographic 
method over 6 years to explore the labor and birth experiences of childhood sexual abuse survivors. Participant observation and interview data from seven survivors and eight health care providers, in addition to anecdotal material from the literature, was utilized during data analysis. Rhodes and Hutchinson (1994) found that women can both forget and remember the abuse. Furthermore, they reported that the birth experience was reminiscent of survivors' past abuse, and that survivors can be forced to remember the past abuse due to the similarity of bodily sensations felt when delivering a baby (Rhodes \& Hutchinson, 1994). Rhodes and Hutchinson (1994) also identified that having control during labor is important to survivors. These findings align with Parratt's (1994) work. In addition to survivors, five nurse-midwives and three labor and birth nurses took part in this study that found the labor styles of survivors of childhood sexual abuse to include fighting, taking control, surrendering, and retreating. Surrendering and retreating both involved survivors dissociating during labor. Taking control involved survivors wanting to direct their labor experience and to make decisions for themselves during labor. In this vein, it was reported that many survivors wrote birth plans or sought out midwifery care. Rhodes and Hutchinson (1994) concluded that to improve the health care experience for women who have survived childhood sexual abuse, clinicians must understand the connection between a history of sexual abuse and labor and birth, as well as the repercussions this history can have.

Burian (1995), a practicing midwife, conducted a descriptive, qualitative study in the United States with five survivors of sexual abuse, two nurses who were also survivors, one obstetric nurse, and one childbirth educator. Interviews were conducted with the nine participants and subsequently themes were identified. Burian (1995) reported that the strongest themes were disclosure and validation, avoidance of health care, frequent somatic complaints, issues of control, and dissociation during medical procedures. With regard to avoidance of health care, 
survivors reported looking for holistic providers when they did seek care, specifically midwives, nurse practitioners, acupuncturists, and chiropractors (Burian, 1995). Burian (1995) identified that survivors can benefit from having control and a trusting relationship in the context of the health care setting. Based on her findings, Burian (1995) shared strategies for sensitive care for health care providers to utilize when working with survivors. These suggested strategies include giving a woman complete control during vaginal exams and repeatedly assuring her that she is safe during labor and birth.

Seng et al. (2002) conducted the only qualitative study on women with a history of childhood sexual abuse and abuse-related posttraumatic stress in an effort to understand what these women view as ideal maternity health care practices. Interviews from 15 women were conducted and analyzed, following the qualitative research design of narrative analysis. Three groups emerged from this analysis: (a) women far along in recovery, (b) women who were not safe, and (c) women who were not ready to "know" (Seng et al., 2002, p. 360). In the first group, the women were in safe relationships and had appropriate social support. Their ideal health care provider was a "collaborative ally" (Seng et al., 2002, p. 363). Overall, these women had the best childbirth experiences. In the second group, the women were not safe and did not have adequate social support. They sought safety and their ideal health care provider was a "compassionate authority figure" (Seng et al., 2002, p. 363). The third group of women were not ready to address or discuss their past histories of sexual trauma. Their level of safety was uncertain and their ideal health care provider was a "therapeutic mentor" (Seng et al., 2002, p. 363). Based on the results, Seng et al. (2002) summarized the "desired practices" survivors hope for from their health care providers (p. 364). These included asking about a history of abuse, acknowledging the longstanding effects of the trauma, assessing for issues related to the abuse, arranging for the 
specific needs of each patient, avoiding triggers, and advocating for social support. These desired practices are comparable to the universal precautions that resulted from Coles and Jones's (2009) research.

Coles and Jones (2009) completed a descriptive, qualitative study with survivors of childhood sexual abuse in Australia. Semi-structured, in-depth interviews were conducted with 18 women to explore their perinatal health care experiences and early postpartum experiences of mothering. Two key themes were identified: safety issues for survivors and their newborns during the health care encounter, and ways to make the health care encounter safer. For the first key theme, clinical exams, especially vaginal exams, caused memories of the past abuse and some survivors also experienced flashbacks when their babies were examined. Ways to make the health care encounter safer included the following themes: the relationship with the health care provider, access to health care, and the provider's awareness of the longstanding effects of trauma. As a result of their research, the authors created "universal precautions," (Coles \& Jones, 2009, p. 235), which include recommendations that clinicians should give survivors control, explain procedures, ask for consent before touching them or their newborns, and stop the exam upon request or signs of distress.

Schwerdtfeger and Wampler (2009) were the only researchers to qualitatively examine the impact of past sexual trauma on women's current pregnancy experiences (all other research has been retrospective). Following a descriptive phenomenological approach, the authors' aim was to understand the lived experience of pregnant women who have a history of sexual trauma. One-on-one, semi-structured interviews (23 questions) were conducted with 10 pregnant women from west Texas. Participants were between 18 and 34 weeks gestation, and the majority $(n=9)$ were Caucasian. Four dominant categories arose from data analysis: (a) negative consequences 
of sexual trauma, (b) becoming a survivor, (c) pregnancy: a new beginning beyond sexual trauma, and (d) the integration of sexual trauma and motherhood (Schwerdtfeger \& Wampler, 2009). The first category, negative consequences of sexual trauma, had five sub-themes: ongoing reminders, changed social relationships, altered sex and sexuality, loss of self-regard, and overwhelming emotions (Schwerdtfeger \& Wampler, 2009). The second category, becoming a survivor, resulted in the following subthemes: finding an inner strength, gaining a new perspective, using a support system, and letting it out (i.e., discussing the past; Schwerdtfeger \& Wampler, 2009). The third category, pregnancy: a new beginning beyond sexual trauma, had four subthemes: distinctly different experiences, a new beginning, a new relationship, and a new found hope (Schwerdtfeger \& Wampler, 2009). The fourth category, the integration of sexual trauma and motherhood, focused on three subthemes largely centered around the women's care of their children: being more protective, how the gender of their child impacted their mothering, and future hopes for their child (Schwerdtfeger \& Wampler, 2009). In this category, participants described intense worry and concern about their daughters being sexually abused and how they sought to protect them. From the categories and subthemes as a whole, Schwerdtfeger and Wampler (2009) concluded that pregnancy "may function as a catalyst for posttraumatic growth and healing" in some pregnant women who have experienced a past sexual trauma (p. 116).

Roller (2011) conducted a grounded theory study aimed at creating a theoretical framework to describe childhood sexual abuse survivors' management of "intrusive reexperiencing" (p. 488). The study was conducted in the United States and recruitment occurred in an urban, low-socioeconomic, Midwest setting. Twelve survivors of childhood sexual abuse were interviewed individually and data analysis followed the constant comparative method. The majority of participants $(n=8)$ were African American. The psychosocial problem was the 
challenges survivors faced when they were triggered to relive their childhood sexual abuse by having flashbacks during the perinatal period. Triggers included pregnancy itself, as well as medical procedures. The core category that emerged was "moving beyond the pain" (Roller, 2011, p. 489). The framework the researchers developed describes how survivors moved beyond the pain of their past in three phases: reliving it, taking charge of it, and getting over it. Reliving it resulted from triggers such as the physical changes of pregnancy, like the fetus kicking, as well as vaginal exams. Taking charge of it involved childhood sexual abuse survivors choosing a specific health care provider, usually female, or being their own advocates. Getting over it represented how woman coped with their past to move forward.

Halvorsen et al. (2013) conducted semi-structured interviews with 10 rape survivors regarding their experience of giving birth for the first time, A purposeful sample of women in Northern Norway who were not currently pregnant and were not suffering from major mental illness was chosen. Participants had both vaginal and cesarean births. Through content analysis the main theme reported was being back in the rape with two categories: (a) reactivation of the rape during labor with the subcategories struggle, surrender, and escape and (b) retraumatization after birth with the subcategories objectified, dirtied, and alienated body (Halvorsen et al., 2013). Regardless of birth method, women relived their past and felt retraumatized and dirty after birth.

A meta-synthesis is aimed at uncovering the connections between qualitative study participants and findings to create one comprehensive synthesis (Noblit \& Hare, 1988;

Sandelowski \& Barroso, 2007). Montgomery (2013) conducted the only meta-synthesis on the maternity care needs of women who were sexually abused in childhood. This meta-synthesis integrated the findings of eight qualitative studies (both published research $[\mathrm{N}=5$ also included in 
this systematic review] and unpublished doctoral dissertations [ $\mathrm{N}=3$ which were reviewed and excluded from this systematic review]) on childhood sexual abuse survivors' needs during childbearing. Control, remembering, vulnerability, dissociation, disclosure, and healing were identified as key themes, with control being the strongest theme (Montgomery, 2013). Control in the health care setting and a positive relationship with health care providers resulted in survivors feeling safe and possibly even having a healing experience (Montgomery, 2013). In contrast, lack of control and lack of a trusting relationship with health care providers can cause survivors to feel re-traumatized. Montgomery (2013) concluded that health care professionals are charged to help survivors feel safe.

Montgomery et al. (2015a, 2015b) undertook a feminist narrative study in the United Kingdom to explore the maternity care experience of childhood sexual abuse survivors and published their findings in two articles. These researchers use the voice-centered relational method and thematic analysis. Four overarching themes were identified: women's narrative of self (e.g., denial, shame, guilt), women's narrative of relationship (e.g., abandonment, control, disassociation, feeling alone, flashbacks, protection of self, powerlessness), women's narrative of context (e.g., hidden aspect of sexual abuse, disclosure, silence), and the childbirth journey (e.g., lack of ability to disclose) (Montgomery et al., 2015a). Silence regarding the past was the identified as a commonality among all women's narratives. Additionally, Montgomery et al. (2015b) reported that re-enactment of abuse occurred through intimate procedures, pain, loss or control, encounters with strangers, and unexpected triggers (e.g., epidurals). Importantly, reenactment of the abuse occurred when survivors experienced events related to their sense of agency. The conclusions were that trusting relationships with care providers are central to 
women feeling safe. Additionally, midwives and women's health providers should discuss trauma histories with women to break the silence.

LoGiudice and Beck (2016) conducted a descriptive, phenomenological study on the pregnancy and labor and birth experience of survivors of sexual abuse. The study was conducted in the United States, and included eight self-identifying survivors with at least one childbearing experience. Interviews and data analysis yielded seven overarching themes that collectively describe the essence of survivors' pregnancy and labor and birth experience. They are summarized as follows: (a) Survivors had a desire to be asked about their past history and to be screened for sexual violence; (b) The childbearing experience was a complex, emotional roller coaster, permeated by the past; (c) Survivors had flashbacks to their past during vaginal exams, epidural procedures, and when their infant was placed skin-to-skin, or survivors compartmentalized the past abuse from the current childbearing experience, described as 'the all or nothing experience'; (d) Survivors felt unable to speak up for themselves and were uninformed about what was happening; (e) Survivors lacked support from family or health care providers; (f) Control was a central concern, and survivors pursued control through choosing a female health care provider, and deciding for themselves on infant feeding methods; (g) Survivors struggled with keeping their children safe and undertook many efforts to overprotect both male and female children from birth into adulthood.

\section{Discussion}

This systematic literature review provides a detailed summary of the existing literature on the childbearing experiences of women who have experienced sexual abuse. It is imperative for nurses and other women's health care providers to utilize evidence from the literature as they provide maternity care to women who have experienced sexual abuse. Overall, this review has 
revealed that lack of control, dissociation, and flashbacks were themes commonly reported by women regarding their childbearing experiences. Re-experiencing of the trauma occurred during various stages of labor and birth and was re-traumatizing to survivors. Often common procedures associated with labor and birth, such as vaginal examinations and pushing during the second stage of labor, were triggers for survivors; however, it is important to note that less commonly thought of triggers, such as having an epidural, were also reported. During the epidural placement, survivors have shared that they could not see what was taking place and were being told to stay still, both of which were reminiscent to abuse (LoGiudice \& Beck, 2016). Survivors also feel the innate need to protect their offspring from harm given their own personal histories of trauma.

The literature highlights the need for survivors to have control in the health care setting to mitigate the re-experiencing of past trauma. Allowing women to make choices for themselves during labor, as well as forming a positive therapeutic relationship with their care providers, has been identified as beneficial during the childbearing experience. Having a sense of self-agency throughout pregnancy and during labor and birth is essential for survivors of sexual abuse.

\section{Limitations and Strengths}

The major strength of this systematic review is the manner in which the review was conducted, using both a research librarian as well as hand-searching all article reference lists to ensure inclusiveness. However, a notable limitation of the review is there are no quantitative studies in this area of research. Additionally, the span of time between women's childbirth and their participation in the studies varied considerably, from 1 week to 28 years. Another limitation is that this review did not identify any studies that reported on the current mental health status of participants; therefore, it is unknown where on the continuum of post-traumatic growth these 
women may have been at the time of the research study.

\section{Implications for Practice}

A strong potential exists to increase a survivor's self-efficacy through a positive birthing experience (Halvorsen et al., 2013; Rhodes \& Hutchinson, 1994). Forming a therapeutic relationship and discussing the past trauma in the context of the current health care experience are both beneficial to survivors. Nurses can form this relationship on labor and birth units, as can

clinicians in antenatal settings, to help women have a more positive health care experience and to prevent their being re-traumatized. Additionally, ensuring survivors are adequately informed ahead of time about what to expect during all procedures, especially vaginal exams and epidural placements, is necessary to prevent flashbacks. As an example, nurses can first explain what to expect, and then explain what is happening throughout the epidural placement, to ensure a woman feels safe and is aware of what is occurring to her body.

Furthermore, regaining or remaining in control is central to survivors' childbearing experience. As a result, survivors often seek midwifery care (Burian, 1995; Parratt, 1994; Rhodes \& Hutchinson, 1994; Seng et al., 2002). As central tenants of midwifery care, a woman is an active participant in health care decisions and her past life experiences are acknowledged. Nurses can maintain the feeling of safety and control for survivors by offering acceptable choices for how to be positioned during labor (e.g., ambulating, side-lying, out of bed in a chair or on a birthing ball), as well as maintaining privacy during pushing by keeping women covered. This knowledge is essential for nurses and all women's health care providers when caring for survivors of abuse.

\section{Implications for Policy}

The Institute of Medicine (2011) identified universal screening of all women of childbearing age 
for intimate partner violence as a key element of preventive health services for women, and the Association of Women's Health, Obstetric, and Neonatal Nurses states that "women should be universally screened for intimate partner violence in private, safe settings where health care is provided (2015, p. 405). Both the American College of Obstetricians and Gynecologists (2012) and the American College of Nurse-Midwives (2013) offer clear guidance on the importance of screening pregnant women for past and/or current sexual abuse and domestic violence. Identifying women who have or are experiencing sexual abuse can allow for therapeutic disclosure, a plan for safety, and discussions regarding the potential impact such a history can have on the childbearing experience. Ensuring these screenings are built into all electronic health records and tied to reimbursement have the potential to positively affect the frequency with which women's health care providers screen women (LoGiudice, 2015).

\section{Conclusion}

The childbearing experiences of $20 \%$ of women cannot be ignored. It is clear that survivors of sexual abuse have unique health care needs, especially in the context of maternity care. By studying and understanding survivors' experiences, women's health care providers can move forward to provide control to survivors during health care encounters and to form therapeutic relationships to help these women have positive childbearing experiences. 



\section{References}

American College of Nurse-Midwives. (2013). Violence against women [Position statement]. Silver Spring, MD: Author. Retrieved from http://www.midwife.org/ACNM/files/ACNMLibraryData/UPLOADFILENAME/000000000091 /Violence-Against-Women-Sept-2013.pdf

American College of Obstetricians and Gynecologists. (2012). Committee Opinion No. 518: Intimate partner violence. Obstetrics and Gynecology, 119(2 Pt. 1), 412-417. doi:10.1097/AOG.0b013e318249ff74

Association of Women's Health, Obstetric, and Neonatal Nurses. (2015). Intimate partner violence [Position Statement]. Journal of Obstetric, Gynecologic, \& Neonatal Nursing, 44, 405408. doi: 10.1111/1552-6909.12567

Basile, K. C., Smith, S. G., Breiding, M. J., Black, M. C., \& Mahendra, R. R. (2014). Sexual violence surveillance: Uniform definitions and recommended data elements, version 2.0. Atlanta, GA: National Center for Injury Prevention and Control of the Centers for Disease Control and Prevention. Retrieved from http://www.cdc.gov/violenceprevention/pdf/sv_surveillance_definitionsl-2009-a.pdf

Belenky, M. F., Clinchy, B. M., Goldberger, N. R., \& Tarule, J. M. (1997). Women's ways of knowing: The development of self, voice, and mind ( $10^{\text {th }}$ anniversary ed.). New York, NY: BasicBooks, Inc.

Benedict, M. I., Paine, L. L., Paine, L. A., Brandt, D., \& Stallings, R. (1999). The association of childhood sexual abuse with depressive symptoms during pregnancy, and selected pregnancy outcomes. Child Abuse and Neglect, 23(7), 659-670.

Breiding, M. J., Smith, S. G., Basile, K. C., Walters, M. L., Chen, J., \& Merrick, M. T. (2014). Prevalence and characteristics of sexual violence, stalking, and intimate partner violence victimization-National Intimate Partner and Sexual Violence Survey, United States, 2011. Morbidity and Mortality Weekly Report, 63(8), 1-18. Retrieved from http://www.cdc.gov/mmwr/preview/mmwrhtml/ss6308a1.htm

Burian, J. (1995). Helping survivors of sexual abuse through labor. MCN: The American Journal of Maternal/Child Nursing, 20(5), 252-256.

Cantor, D., Fisher, B., Chibnall, S., Townsend, R., Lee, H., Bruce, C., \& Thomas, G. (2015). Report on the AAU Campus Climate Survey on Sexual Assault and Sexual Misconduct. Rockville, MD: Westat. Retrieved from http://www.aau.edu/uploadedFiles/AAU_Publications/AAU_Reports/Sexual_Assault_Campus_ Survey/Report\%20on\%20the\%20AAU\%20Campus\%20Climate\%20Survey\%20on\%20Sexual\% 20Assault\%20and\%20Sexual\%20Misconduct.pdf

Coles, J., \& Jones, K. (2009). “Universal precautions”: Perinatal touch and examination after 
childhood sexual abuse. Birth, 36(3), 230-236. doi:10.1111/j.1523-536X.2009.00327.x

Halvorsen, L., Nerum, H., Oian, P., \& Sørlie, T. (2013). Giving birth with rape in one's past: A qualitative study. Birth, 4O(3), 182-191. doi:10.1111/birt.12054

Hanan, M.R. (2006). An experience of sexual abuse, grief and its effects on childbirth. MIDIRS Midwifery Digest, 16(1), 37-41.

Heimstad, R., Dahloe, R., Laache, I., Skogvoll, E., \& Schei, B. (2006). Fear of childbirth and history of abuse: Implications for pregnancy and delivery. Acta Obsetricia et Gynecologica Scandinavica, 85(4), 435-440.

Institute of Medicine. (2011). Clinical preventive services for women: Closing the gaps [Report brief]. Washington, DC: Author. Retrieved from https://www.nationalacademies.org/hmd/ /media/Files/Report\%20Files/2011/ClinicalPreventive-Services-for-Women-Closing-theGaps/preventiveservicesforwomenreportbrief_updated2.pdf

Jacobs, J. L. (1992). Child sexual abuse victimization and later sequelae during pregnancy and childbirth. Journal of Child Sexual Abuse, 1(1), 103-112.

Leeners, B., Rath, W., Block, E., Görres, G., \& Tschudin, S. (2014). Risk factors for unfavorable pregnancy outcome in women with adverse childhood experiences. Journal of Perinatal Medicine, 42(2), 171-178. doi:10.1515/jpm-2013-0003

Lewars, C. (2006). The life of my body. Midwifery Today, 80, 24-25.

LoGiudice, J. A. (2015). Prenatal screening for intimate partner violence: A qualitative meta-synthesis. Applied Nursing Research, 28(1), 2-9. doi:10.1016/j.apnr.2014.04.004

LoGiudice, J. A., \& Beck, C. T. (2016). The lived experience of childbearing from survivors of sexual abuse: "It was the best of times, It was the worst of times." Journal of Midwifery and Women's Health, 61(4), 474-181. doi:10.1111/jmwh.12421

Montgomery, E. (2013). Feeling safe: A metasynthesis of the maternity care needs of women who were sexually abused in childhood. Birth, 40(2), 88-95. doi:10.1111/birt.12043

Montgomery, E., Pope, C., \& Rogers, J. (2015a). A feminist narrative study of the maternity care experiences of women who were sexually abused in childhood. Midwifery, 31(1), 54-60. doi:10.1016/j.midw.2014.05.010

Montgomery, E., Pope, C., \& Rogers, J. (2015b). The re-enactment of childhood sexual abuse in maternity care: A qualitative study. BMC Pregnancy and Childbirth, 15(194), 1-7. doi:10.1186/s12884-015-0626-9

Nerum, H., Halvorsen, L., Oian, P., Sørlie, T., Straume, B., \& Blix, E. (2010). Birth outcomes in 
primiparous women who were raped as adults: A matched controlled study. BJOG: An International Journal of Obstetrics and Gynaecology, 117(3), 288-294.

doi:10.1111/j.1471-0528.2009.02454.x

Noblit, G. W., \& Hare, R. D. (1988). Meta-ethnography: Synthesizing qualitative studies. Newbury Park, CA: Sage Publications, Inc.

Parratt, J. (1994). The experience of childbirth for survivors of incest. Midwifery, 10(1), 26-39.

Rhodes, N., \& Hutchinson, S. (1994). Labor experiences of childhood sexual abuse survivors. Birth, 21(4), 213-220.

Roller, C. G. (2011). Moving beyond the pain: Women's responses to the perinatal period after childhood sexual abuse. Journal of Midwifery \& Women's Health, 56(5), 488-493. doi:10.1111/j.1542-2011.2011.00051.x

Rose, A. (1992). Effects of childhood sexual abuse on childbirth: One woman's story. Birth, 19(4), 214-218.

Rouf, K. (1999). Child sexual abuse and pregnancy: A personal account. The Practising Midwife, 2(6), 29-31.

Sandelowski, M., \& Barroso, J. (2007). Handbook for synthesizing qualitative research. New York, NY: Springer Publishing Company, Inc.

Schwerdtfeger, K. L., \& Wampler, K. S. (2009). Sexual trauma and pregnancy: A qualitative exploration of women's dual life experience. Contemporary Family Therapy, 31(2), 100-122.

Seng, J. S., Sparbel, K. J., Low, L. K., \& Killion, C. (2002). Abuse-related posttraumatic stress and desired maternity care practices: Women's perspectives. Journal of Midwifery and Women's Health, 47(5), 360-370.

Skinner, A. C. (2010). Power, control and the "difficult" patient: Hidden dimensions to caring for survivors of sexual abuse. Journal of Midwifery and Women's Health, 55(2), 181-182. doi:10.1016/j.jmwh.2009.08.001

Smith, M. (1998a). Childbirth in women with a history of sexual abuse (I). The Practising Midwife, 1(5), 20-23.

Smith, M. (1998b). Childbirth in women with a history of sexual abuse (II). A case history approach. The Practising Midwife, 1(6), 23-27.

Stoltenborgh, M., van Ijzendoorn, M. H., Euser, E. M., \& Bakermans-Kranenburg, M. J. (2011). A global perspective on child sexual abuse: Meta-analysis of prevalence around the world. Child Maltreatment, 16(2), 79-101. doi:10.1177/1077559511403920 
Tilley, J. (2000). Sexual assault and flashbacks on the labour ward. The Practising Midwife, 3(4), $18-20$.

Waymire, V. (1997). A triggering time: Childbirth may recall sexual abuse memories. AWHONN Lifelines, 1(2), 47-50. 
Table 1. Qualitative Studies of the Childbearing Experiences of Survivors of Sexual Abuse

\begin{tabular}{|c|c|c|c|c|c|c|}
\hline $\begin{array}{l}\text { Author(s)/ } \\
\text { Year }\end{array}$ & Country & Discipline & Sample & Focus & $\begin{array}{l}\text { Qualitative } \\
\text { Research } \\
\text { Design and } \\
\text { Data Analysis }\end{array}$ & Results \\
\hline
\end{tabular}

\begin{tabular}{|c|c|c|c|c|c|c|}
\hline $\begin{array}{l}\text { Burian, } \\
1995\end{array}$ & $\begin{array}{l}\text { United } \\
\text { States }\end{array}$ & Nursing & $\begin{array}{l}\mathrm{N}=9 ; \\
5 \text { survivors, } \\
2 \text { nurses \& } \\
\text { survivors, } \\
1 \text { nurse, } \\
1 \text { childbirth } \\
\text { educator }\end{array}$ & $\begin{array}{l}\text { Childbirth (labor } \\
\& \text { birth) } \\
\text { experience of } \\
\text { sexual abuse } \\
\text { survivors }\end{array}$ & $\begin{array}{l}\text { Descriptive, } \\
\text { Thematic } \\
\text { Analysis }\end{array}$ & $\begin{array}{l}\text { Strongest themes: disclosure an } \\
\text { validation, avoidance of health } \\
\text { care, frequent somatic } \\
\text { complaints, issues of control, } \\
\text { and dissociation during medical } \\
\text { procedures. }\end{array}$ \\
\hline
\end{tabular}

$\begin{array}{llll}\begin{array}{l}\text { Coles \& Australia } \quad \text { Medicine } \\ \text { Jones, }\end{array} & & \text { CSA survivors' Descriptive, } \\ 2009 & \text { experiences of Thematic } & \text { perinatal } \\ & \text { professional touch } \\ & \text { and examination } \\ & \text { of themselves and } \\ & \text { their babies (labor } \\ & \& \text { birth, \& the } \\ & \text { postpartum } \\ & \text { period) }\end{array}$

Two key themes: safety issues for survivors $\&$ their babies during the health care encounter, and ways to make the health care encounter safer.

\begin{tabular}{|c|c|c|c|}
\hline $\begin{array}{l}\text { Halvorsen, Norway } \\
\text { Nerum, Øian, } \\
\& \text { Sørlie, } 2013\end{array}$ & $\begin{array}{l}\text { Nursing \& } \\
\text { Medicine }\end{array}$ & $\mathrm{N}=10$ & $\begin{array}{l}\text { Rape survivors } \\
\text { experience } \\
\text { of giving birth for } \\
\text { the first time }\end{array}$ \\
\hline
\end{tabular}

Main theme: "Being back in the rape" with two categories: "reactivation of the rape during labor and re-traumatization after birth" 


\begin{tabular}{|c|c|c|c|c|c|c|}
\hline $\begin{array}{l}\text { LoGiudice } \\
\text { \& Beck, } \\
2016\end{array}$ & $\begin{array}{l}\text { United } \\
\text { States }\end{array}$ & Nursing & $\mathrm{N}=8$ & $\begin{array}{l}\text { Childbearing } \\
\text { experiences } \\
\text { (pregnancy, labor } \\
\text { \& birth }\end{array}$ & $\begin{array}{l}\text { Descriptive } \\
\text { Phenomenology, } \\
\text { (Colaizzi, } \\
\text { 1978) }\end{array}$ & $\begin{array}{l}7 \text { themes: 1) No one asked me. } \\
\text { Just ask me! 2) An emotional } \\
\text { roller coaster: From excitement } \\
\text { to grief for what could have } \\
\text { been a better experience; 3) All } \\
\text { of a sudden I was that little girl } \\
\text { again and/or I } \\
\text { compartmentalized it: The all } \\
\text { or nothing experience; 4) Am I } \\
\text { even here? Nothing was } \\
\text { explained and I had no voice; } \\
\text { 5) All to familiar: No support, } \\
\text { nowhere to turn; 6) Holding on } \\
\text { to the choices I can make: } \\
\text { Who my doctor is and how I } \\
\text { feed my baby; } \\
\text { 7) Overprotection: Keeping my } \\
\text { child safe. }\end{array}$ \\
\hline $\begin{array}{l}\text { Montgomery, } \\
\text { Pope, \& } \\
\text { Rogers, } \\
\text { 2015a; } 2015 \text { b }\end{array}$ & $\begin{array}{l}\text { United } \\
\text { Kingdom }\end{array}$ & Nursing & $\mathrm{N}=9$ & $\begin{array}{l}\text { Pregnancy } \\
\text { \& Birth }\end{array}$ & $\begin{array}{l}\text { Feminist } \\
\text { Narrative } \\
\text { Study, } \\
\text { The voice- } \\
\text { centered } \\
\text { relational } \\
\text { model and } \\
\text { thematic } \\
\text { analysis }\end{array}$ & $\begin{array}{l}\text { Re-enactment of the abuse } \\
\text { through how intimate } \\
\text { procedures were performed } \\
\text { and through subjective internal } \\
\text { factors related to one's sense } \\
\text { of agency (2015a). Four } \\
\text { overarching themes: women's } \\
\text { narrative of self, of } \\
\text { relationship, and of context, } \\
\text { and the childbirth journey, } \\
\text { each linked by the concept of } \\
\text { silence }(2015 \mathrm{~b}) \text {. }\end{array}$ \\
\hline
\end{tabular}




\begin{tabular}{|c|c|c|c|c|c|c|}
\hline $\begin{array}{l}\text { Parratt, } \\
1994\end{array}$ & Australia & Nursing & $N=6$ & $\begin{array}{l}\text { Childbirth } \\
\text { (labor \& birth) } \\
\text { experience of } \\
\text { CSA incest } \\
\text { survivors }\end{array}$ & $\begin{array}{l}\text { Phenomenology, } \\
\text { (Patton, } \\
\text { 1990) }\end{array}$ & $\begin{array}{l}\text { Memories of past abuse were } \\
\text { triggered during childbirth. } \\
\text { Privacy, touch, and control are } \\
\text { important aspects of survivors' } \\
\text { experiences. }\end{array}$ \\
\hline $\begin{array}{l}\text { Rhodes \& } \\
\text { Hutchinson, } \\
1994\end{array}$ & $\begin{array}{l}\text { United } \\
\text { States }\end{array}$ & Nursing & $\begin{array}{l}\mathrm{N}=15 \\
7 \text { survivors, } \\
5 \text { nurse- } \\
\text { midwives, \& } \\
3 \text { labor \& } \\
\text { delivery } \\
\text { nurses }\end{array}$ & $\begin{array}{l}\text { Childbirth } \\
\text { (labor \& birth) } \\
\text { experience of } \\
\text { CSA survivors }\end{array}$ & $\begin{array}{l}\text { Ethonography, } \\
\text { (Spradley, } \\
\text { 1979) }\end{array}$ & $\begin{array}{l}\text { Forgetting and remembering. } \\
\text { Birth can cause forced } \\
\text { remembering: body memories. } \\
\text { Control is important for } \\
\text { survivors. Survivors' laboring } \\
\text { styles include fighting, taking } \\
\text { control, surrendering, and } \\
\text { retreating. }\end{array}$ \\
\hline $\begin{array}{l}\text { Roller, } \\
2011\end{array}$ & $\begin{array}{l}\text { United } \\
\text { States }\end{array}$ & Nursing & $\mathrm{N}=12$ & $\begin{array}{l}\text { Perinatal period } \\
\text { (pregnancy, labor, } \\
\& \text { birth) of CSA } \\
\text { survivors }\end{array}$ & $\begin{array}{l}\text { Grounded } \\
\text { Theory, } \\
\text { Constant } \\
\text { comparative } \\
\text { analysis } \\
\text { (Glaser \& } \\
\text { Strauss, 1967; } \\
\text { Strauss \& } \\
\text { Corbin, 1998) }\end{array}$ & $\begin{array}{l}\text { Core category: Moving beyond } \\
\text { the pain. CSA survivors } \\
\text { manage the re-experiencing of } \\
\text { their past abuse triggered in the } \\
\text { perinatal period by } 3 \\
\text { processes: reliving it, taking } \\
\text { charge of it, \& getting over it. }\end{array}$ \\
\hline $\begin{array}{l}\text { Schwerdtfeger } \\
\text { \& Wampler, } \\
2009\end{array}$ & $\begin{array}{l}\text { United } \\
\text { States }\end{array}$ & $\begin{array}{l}\text { Human } \\
\text { Development } \\
\text { and Family } \\
\text { Science }\end{array}$ & $\mathrm{N}=10$ & $\begin{array}{l}\text { Current pregnancy } \\
\text { experience of } \\
\text { survivors of } \\
\text { sexual trauma }\end{array}$ & $\begin{array}{l}\text { Descriptive } \\
\text { Phenomenology, } \\
\text { (Colaizzi, } \\
\text { 1978) }\end{array}$ & $\begin{array}{l}4 \text { dominant categories: }(1) \\
\text { negative consequences of } \\
\text { sexual trauma, (2) becoming a } \\
\text { survivor, (3) pregnancy: a new } \\
\text { beginning beyond sexual } \\
\text { trauma, \& (4) the integration } \\
\text { of sexual trauma and } \\
\text { motherhood. }\end{array}$ \\
\hline
\end{tabular}


Seng, Sparbel, United Low, Killion, States 2002

$\begin{array}{lll}\text { Nursing N }=15 \quad \begin{array}{l}\text { Childbearing } \\ \text { (pregnancy \& } \\ \text { birth) }\end{array} & \begin{array}{l}\text { Narrative } \\ \text { Analysis, } \\ \text { (Riessman, }\end{array} \\ \text { perspectives of } & \text { 1993) } \\ \text { CSA and abuse- } & \\ & \text { related } & \\ \text { posttraumatic } & \\ & \text { stress survivors } & \end{array}$

3 groups emerged: (1) women far along in recovery, (2)

women who were not safe, \&

(3) women who were not ready to "know".

Note $. \mathrm{CSA}=$ childhood sexual abuse 